\title{
Supply chain management and lean concept in construction: a case of Ghanaian building construction industry
}

DOI 10.2478/otmcj-2019-0010

Received July 11, 2019; accepted November 28, 2019

\begin{abstract}
Supply chain management (SCM), for the past two decades, has been identified by manufacturing industries as a new way of doing business. Construction, similar to manufacturing and other services industries, is experiencing emerging trends that are aimed at giving ultimate satisfaction to the end user. Lean construction is a way to design production systems in order to minimize waste of materials, time and efforts which generate maximum possible amount of value. This research looked into how SCM can benefit the Ghanaian building construction industry through the application of lean concept. The purpose of this study is to assess the level of collaboration and coordination in planning of activities among construction industry players and investigate into the sources of waste in construction. The study, employing survey and case study approaches, collected data through structured questionnaires, in-depth interviews and direct observation of ongoing projects on KNUST campus. One sample $t$-test was used to analyse the data. The findings pointed out that the level of coordination and collaboration in planning among industry players were very appreciable though there still exist room for improvement.
\end{abstract}

Keywords: construction, lean, supply chain management, value, waste

\section{Introduction}

Supply chain management (SCM), for the past two decades, has been identified by manufacturing industries as a new way of doing business (O’Brien et al. 2008).

*Corresponding author: Ali Boateng, Directorate of Works and Physical Development, Kumasi Technical University, Post Office Box 854, Kumasi, Ghana, E-mail: ali.boateng@kstu.edu.gh
The ever-changing manufacturing environment such as development of Information Technology (Internet), globalization and sophisticated customers who demand increasing product variety, lower cost, better quality and faster response has accounted for the implementation of this new approach. As explained by Christopher (2016), SCM is concerned with the management of upstream and downstream relationships with suppliers and customers in order to deliver superior customer value at less cost to the supply chain as a whole. Christopher (2016) continued that the primary focus of SCM includes seeking to achieve linkage and coordination between the processes of other entities, reducing buffer of inventory that exists between organizations in a chain through information sharing, as well as ensuring cooperation and trust among all those involved in the supply chain.

Construction SCM is an emerging area of practice which is inspired by but differs substantially from manufacturing SCM which places emphasis on modelling volume production. Construction SCM, on the other hand, is concerned with the coordination of discrete quantities of materials delivered to specific construction projects (O'Brien et al. 2008). The construction industry is generally known to be a very vibrant and primary contributor to the economy of every nation in terms of employment generation and gross domestic product. It is evident in the employment opportunities that it offers skilled and unskilled labours, from engineers and consultants to artisans and labourers (Ofori 2012).

Construction, similar to manufacturing and other services industries, is experiencing emerging trends that are aimed at giving ultimate satisfaction to the end user. As in the manufacturing context, construction companies are facing increasing competition and customers are requiring lower cost, higher quality, shorter execution duration and more reliable schedule (O'Brien et al. 2008). The industry is characterized by the adoption of traditional methods of procurement and planning project executions with very little room for logistics and SCM. It has led to 
a situation where most projects are completed well over the contract duration while incurring avoidable costs, hence a reduction in turnover (O'Brien et al. 2008).

One strategy for coordinating within and between firms with a focus on achieving efficiency, eliminating waste or overburden and creating value in products is the concept of lean management (Stock and Boyers 2009). Lean concept, which was coined in a book called The Machine That Changed The World, co-authored by Jim Womack, Daniel Jones and Daniel Roos, evolved from the Toyota Production System (TPS) in Japan and is a philosophy that considers the expenditure of resources for any goal other than the creation of value to be wasteful for the end customer, and thus a target for elimination (Holweg 2007; Nikakhtar et al. 2015). Holweg (2007) further defines 'value' as any action or process for which a customer would be willing to pay. This concept, which was originally designed to suit the manufacturing industry, has not allowed the construction industry to benefit fully because of the one of a kind type of production as against the mass production in manufacturing. Lean therefore employs continuous improvement efforts that focus on eliminating waste or non-value-adding steps along the supply chain.

Vidhate and Salunkhe (2018) define lean construction as a way to design production systems to minimize waste of materials, time and effort in order to generate the maximum possible amount of value. They further argued that lean construction concerns itself with the holistic pursuit of concurrent and continuous improvements in all dimensions of the built and natural environment. This approach tries to manage and improve construction processes with minimum cost and maximum value by considering customer needs.

While the application of SCM techniques has been known to save millions of dollars by improving on customer service in the manufacturing environment, as stated by Arntzen et al. in Badri et al. (2013), its importance in the construction environment cannot be underestimated. SCM promises to be an engineering basis to design, plan and manage construction projects in a collaborative manner as against the current construction methods that assume hierarchical, decomposition approaches that seek, at best, to optimize individual activities (O'Brien et al. 2008). This ultimately tends to support the fragmentation that plagues the construction industry. On the other hand, according to Liu and Chua (2016), referencing Bertelsen, a poorly designed supply chain regularly increases project costs by $10 \%$ and hence the need to employ best practices if the full benefits of SCM in construction are to be achieved.
Research on improving the quality, performance and delivery in the construction industry in Ghana through the adoption of lean concept largely centres on assessing perceptions of lean construction philosophy, identifying level of knowledge, barriers to the adoption of lean construction and possible means to overcome these barriers as well as the level of contribution of waste minimizing measures and the level of practice of such measures (Ayarkwah et al. 2012a, 2012b; Ayarkwah et al. 2011), without identifying the sources of waste. The main motivation of this research is to provide an approach to improve the performance of the construction industry in Ghana through the concept of lean thinking. The objective of the study is to assess the level of collaboration and coordination in planning among construction industry players and also investigate into the sources and causes of waste in the construction industry. A theoretical framework for SCM and lean construction is explained in Section 2 of the study, whereas Section 3 deals with research methodology. Research results are analysed and discussed in Section 4. Section 5 concludes the study and Section 6 states the research limitations and future direction.

\section{Theoretical framework}

\subsection{Supply chain management}

Stock and Boyers (2009), while stating that there exists much confusion among researchers on the definition of SCM, do acknowledge commonalities like coordination, integration and cooperation among chain members. SCM, according to Christopher (2016) is a network of connected and interdependent organizations mutually and cooperatively working together to control, manage and improve the flow of materials and information from suppliers to users. Christopher (2016) continued that the primary concerns of SCM include (i) achieving linkages and coordination between processes, (ii) removing or eliminating buffers of inventory which exist between organizations in a chain through information sharing, (iii) ensuring cooperation and trust, (iv) managing relationships in order to achieve a more profitable outcome for all parties and (v) achieving competitive advantage.

\subsection{Lean thinking}

Lean thinking was pioneered by the TPS with focus on waste elimination and minimization, manifested in several 
shapes and forms, operational efficiency, continuous flow and customer demand pull, which is otherwise referred in manufacturing as just-in-time production (Fitzsimmons and Fitzsimmons 2011; Aamer 2018). Lean thinking has three guiding principles according to Fitzsimmons and Fitzsimmons (2011) and they are as follows:

- Satisfy the needs of the customer by performing only those activities that add value in the eyes of the customer.

- Define the 'value stream' by flowcharting the process to identify both value-added and non-value-added activities.

- Eliminate waste. Waste in the value stream is any activity that the customer is not willing to pay for.

Tezel et al. (2013) also identified the principles underlying lean thinking as (i) elimination of the process waste, (ii) effective management of the value stream and establishing long-term alliances within the supply chain, (iii) maintenance of reliable and continuous flow of the production and process elements, (iv) pull-based production planning and control, (v) just-in-time delivery of materials and components and (vi) instilling a continuous improvement culture.

According to Holmemo et al. (2018), lean thinking has undergone evolution over the years. They explain that lean thinking, at the early stages, was considered a technical approach based on apply-specific Toyota techniques such as Kanban and just-in-time logistics. It then evolved to a management system for the whole organization and supply chain, with emphasis on contingencies and organizational learning. Lately, lean thinking has become a 'philosophy', something beyond 'what Toyota would do', and has been translated and adopted to a different corporate context.

\subsection{Lean construction: definition and principles}

Lean construction refers to the application and adaptation of principles and concepts underlying the TPS to construction. As in TPS, lean construction focuses on waste reduction, increase in value for the customer and continuous improvement (Dave et al. 2016; Moaveni et al. 2019). Koskela, as pointed out by Moaveni et al. (2019), introduced a new theory of production in construction context which resulted in the integration of three theories of transformation, flow and value creation. This tripartite view of production led to the birth of lean construction as a discipline. Aziz and Hafez (2013) pointed that managing construction under lean differs from typical contemporary practice because it (i) has clear sets of objectives for the delivery process, (ii) is aimed at maximizing performance for the customer at the project level, (iii) designs concurrently product and process and (iv) applies production control throughout the life of the project.

Koskela (2004) explained that Womack and Jones in their book The Machine that Changed the World did not concisely summarized the principles of lean production. Hence in their newer book (1996), Womack and Jones endeavoured to improve the theoretical side of the discussion of lean production. Consequently, they summarized the principles underpinning lean thinking as:

- Precisely specify value by specific product

The central message of this principle is to rethink value from the perspective of the customer. The only thing that adds value in any type of process is the physical or information transformation of the product, service or activity into something the customer wants.

- Identify the value stream for each product

Value stream is about modelling and designing of the production system, including product development, order fulfilment and the production proper, especially with the goal of weeding out avoidable wasteful activities.

- Make value flow without interruption

This principle, while addressing generally the reduction of lead times, refers basically to the method of onepiece flow, instead of a flow consisting of batches.

- Let the customer pull value from the producer

This principle means that the customer is pulling the product from the production system as needed rather than the production system pushing products, often unwanted, onto the customer.

- Pursue perfection

This is all about continuous minimization of waste and maximization of value, that is, continuous improvement.

\subsection{Lean 'wastes'}

Waste should be understood as any inefficiency that results in the use of equipment, materials, labour or capital in larger quantities than those considered as necessary in the production of the activity. Waste therefore includes both the incidence of material losses and the execution of unnecessary work, which generates additional 
cost but does not add value to the product (Ayarkwah et al. 2011). Sutrisno et al. (2018) also simply defined waste as anything that does not provide value to the customer. Ho and Kuo (2015), in referencing Ohno, classified waste into seven categories that are apparent in every manufacturing facility in the world. An eighth category was added by Liker (2004) and it includes waste of overproduction, waste of waiting, waste of transport, waste of overprocessing, waste of inventory, waste of motion, waste of defects and waste of unutilized people.

- Waste of overproduction

This type of waste occurs when production is over what is immediately needed for use, that is, non-valueadding use of available capacity leading to producing more and faster than the customer requires. Inventory stockpile, unbalanced material flow, extra resources and complex inventory management are some of the characteristics of overproduction.

- Waste of waiting

This result from any idle time created while waiting, such as idle time between operations or events. The waiting could be done by employees or customers, either of which is still considered waste. Employees waiting for machines, machines waiting for employees, machines waiting for machines and unplanned equipment breakdown result in waiting and related waste.

- Waste of transport

Any movement of materials or people around any plant that does not add value to the product or service is considered waste of transport, that is, movement of materials, finished goods, parts or information more than required resulting in wasted efforts and energy and adding to cost. Paperwork loop-back, large lot processing, multiple storage location and lack of workplace organization give rise to transport waste.

- Waste of over-processing

This waste is about adding more value than the customer would pay for or any effort that adds no value to the product or service. In other words, processing more than required wherein a simple approach would have sufficed. This generally results from lack of clarity in customer specification, endless refinement and ineffective policies and procedures.

- Waste of motion

This waste is due to any movement of people or machines which does not add value to the product or service. Characteristically, excessive bending and reaching, looking for tools, machines or materials too far apart, confusing motion with work and lack of workplace organization result in waste of motion.

- Waste of inventory

Storing parts, pieces, documentation ahead of requirements, that is, any supply in excess of customer requirements necessary to produce just in time is waste of inventory. Queuing, callers on hold, large storage areas, piles of request, use of large inventories and slow response to change result in this kind of waste.

- Waste of defect

Anything that does not meet customer needs leading to rework, scrap and inspection and repair of materials in inventory. This type of waste results in excessive human resource to rework, scrap, repair or inspect, missed shipment and deliveries and lower profit margins due to rework and scraps.

- Waste of unutilized people

When employees are not leveraged to their own potential, that is, using people to the best of their unique abilities, there is waste of intellect. This usually results from lack of employee involvement, poor morale, status quo not challenged and lack of team activities and accountability.

\subsection{Lean tools}

Numerous tools have been developed along with lean philosophy including Kaizen, Kanban and 5s, with all these sharing similar trait of ensuring continuous improvement. $5 \mathrm{~s}$ is a set of techniques providing a standard approach to housekeeping within Lean. It is designed to improve efficiency, strengthen performance and provide continuous improvement. This is achieved systematically by cleaning and standardizing the whole organizational workplace. The processes through which 5 s goes through are sort, set in order, shine, standardize and sustain (Randhawa and Ahuja 2017). Kaizen also deals with continuous improvement process where everyone is encouraged to come up with small improvement suggestions on a regular basis, process oriented, not straight forward and difficult to sustain in the long run (Ma et al. 2017). Ma et al. further explained that Kaizen aims to produce results from incremental change process, by instilling in everyone within the organization sense of responsibility. Kanban means 
'signboard' or 'billboard' and it works on the basis that each process on a production line pulls just the number and type of components the process requires, at just the right time. It is a means to achieve just in time (Koskela 2004). Ahmad et al. (2016) asserted that Kanban is highly adaptive, focuses on quick response to customer requests, while being based highly on collaborative and self-managing teams.

\section{Methodology}

The research adopted case study and survey approaches, with tools for data collection being face-to-face unstructured interviews, structured questionnaires and direct observation. As referenced by Creswell (2013) in Stake, case study is an in-depth exploration of a programme, an event, an activity, a process or one or more individuals. Time and activity bind these cases, with detailed information collected by the researcher using varying data collection tools and techniques over a sustained period of time. Robson (2002) explained that what is being studied must be a contemporary phenomenon and within its real-life context. According to Yin (2017), case study relies on multiple sources of evidence, with data requiring to converge in a triangulation fashion. Creswell (2013) explained that survey has the primary purpose of generating from a sample to a population, thus permitting the collection and analysis of quantitative data. The study was in-depth to empirically look into a contemporary phenomenon as waste in the construction industry while employing multiple sources of data collection. The researcher did not want to divorce phenomenon from context, by attending to only a few variables as in the case of experiment, and also did not want to focus on history that deals with the entangled situation between phenomenon and context but with non-contemporary events (Yin 2017). The researcher further selected multiple cases of ongoing projects so as to provide strong and reliable evidence, create more convincing theory as the suggestions are grounded intensely in general empirical evidence and allow wider exploring of the research questions (Gustafsson 2017). The researcher also needed to collect as much data within a short period of time and with the intention of making a generalization from the sample. The study therefore adopted survey and case study research methods. Respondents were construction professionals at the office of Works and Physical Development Directorate of Kwame Nkrumah University of Science and Technology (KNUST) and registered with their respective professional bodies as professional members. Based on the Ministry of Works and Housing financial classification of contractors indicating the threshold of total volume of works, apex contractors in the category of D1K1 mandated to execute works in excess of US $\$ 500,000$ were included in the study. These contractors had undertaken works with the University within the last 3 years. Table 1 indicates the background of respondents. The background information on the respondents indicate that their responses can be confidently relied upon as they are enlightened and informed enough to understand the questions both on the surface level and at the technical level.

The cases studied involved four ongoing building projects on the campus of KNUST. Ten construction professionals were interviewed, with 80 questionnaires administered. A total of 63 valid questionnaires were returned, representing a response rate of $78 \%$. Respondents were purposively and conveniently sampled from all construction professionals employed on the building projects that were studied. Questionnaire was primarily divided into two parts. The first part was based on collaboration and coordination in planning activities among industry players. In the second part respondents were asked to rank, in order of importance on a 5-point Likert scale, 24 identified sources of waste on construction sites. Also, respondents were made to share their knowledge and understanding of waste, the possible consequences of waste, tools for waste identification and benefits to an organization on waste identification and

Tab. 1: Respondents information

\begin{tabular}{lcc}
\hline & Frequency & Percent \\
\hline Profession of respondents & 24 & \\
Quantity surveyor & 24 & 38 \\
Architect & 3 & 38 \\
Engineer & 12 & 5 \\
Project manager & 63 & 19 \\
Total & & 100 \\
Academic qualification & 25 & \\
MSc/MPhil/MTech & 36 & 40 \\
BSc/BEng/BTech & 2 & 57 \\
HND & 63 & 3 \\
Total & & 100 \\
Years of experience & 2 & \\
Below 5 years & 18 & 3 \\
5-10 years & 19 & 29 \\
10-15 years & 12 & 30 \\
15-20 years & 12 & 19 \\
Above 20 years & 63 & 19 \\
Total &
\end{tabular}


elimination. The summary of building projects studied is given in Table 2.

Data collected were analysed using descriptive statistics and one-sample $t$-test at $95 \%$ confidence interval. One-sample $t$-test compares the mean of the sample data with a known value when the population standard deviation is unknown or sample size is small. This tool tests a null hypothesis that a population mean is equal to a specific value. Thus SPSS was used to calculate mean scores and standard deviations. Mean scores of greater than 3 were considered statistically significant for the research (Ofori et al. 2012).

\section{Results and discussions}

\subsection{Coordination and collaboration}

As pointed out earlier, SCM largely thrives on coordination, cooperation and integration among all parties along the supply chain which have the ultimate goal of ensuring consumer satisfaction. Mean scores as found in Table 3 indicate that all other stakeholders have very cordial relationship among themselves as mean scores are statistically significant. Respondents rated the level

Tab. 2: Characteristics of case projects

\begin{tabular}{lcl}
\hline Project name & Contract sum (US\$) & Contractor \\
\hline $\begin{array}{l}\text { Construction of 4-Storey } \\
\text { Examination Block }\end{array}$ & $5,500,000$ & $\begin{array}{l}\text { Berock Ventures } \\
\text { Limited } \\
\text { Construction of 4-Storey } \\
\text { N-Block for the College of }\end{array}$ \\
$\begin{array}{l}\text { Engineering } \\
\text { Construction of VIP Ward for }\end{array}$ & $6,200,000$ & $\begin{array}{l}\text { Limited } \\
\text { KNUST Hospital }\end{array}$ \\
$\begin{array}{l}\text { Construction of 3-Storey } \\
\text { Computer Laboratory and }\end{array}$ & $1,500,000$ & $\begin{array}{l}\text { Stivo Company } \\
\text { Limited }\end{array}$ \\
Canteen Block for KNUST JHS & & Limited \\
\hline
\end{tabular}

Tab. 3: Level of coordination and collaboration among industry players

\begin{tabular}{lcccc}
\hline & N & Mean & $\begin{array}{c}\text { Standard } \\
\text { deviation }\end{array}$ & $\begin{array}{c}\text { Standard } \\
\text { error mean }\end{array}$ \\
\hline Consultants & 63 & 4.48 & 0.602 & 0.131 \\
Subcontractors & 63 & 3.90 & 0.944 & 0.206 \\
Major suppliers & 63 & 4.14 & 0.910 & 0.199 \\
Clients & 63 & 4.67 & 0.483 & 0.105 \\
\hline
\end{tabular}

of coordination and collaboration with clients highest, recording a mean of 4.67. Viewing the ultimate goal of successfully completing a project supersedes all other interests, with stakeholders to a project complementing rather than competing with each other. This is fostered in an atmosphere of mutual trust and cooperation. This trait was very noticeable particularly in procurement-related issues among industry players. Long-term relationships have been established with trusted suppliers, stated an interviewee, who know when and what to supply at any given time. The interviewee continued that this relationship further boosts the cash flow of the company as it permits the arrangement of flexible credit terms, while suppliers could also count on the creditworthiness of contractors. Although the current Procurement Act in Ghana favours 'hit and run' when it comes to contractor selection, contractors are more likely to have had previously engagement with the University. Based on previous performance, the University is at ease, retaining the hope that quality work would be delivered at the end of the day. Suppliers too, benefit from mutual trust and loyalty, occasioned by the higher level of collaboration and cooperation existing among industry players. One supplier buttressed this by pointing out that contractors do hardly default on payment thus ensuring their continuous existence in business. The picture thus painted is a win-win situation for all involved.

\subsection{Communication and information sharing}

Effective collaboration and coordination largely thrive on information sharing. Information sharing can also be as effective as the mode and effectiveness of communication. Respondents generally agreed that there existed cordial relationship among all parties with respect to communication and information sharing. This is evident in all respondents' responses attaining significance, as indicated in Table 4. The modes include site meetings, letters, site instructions and phone calls. Electronic means such as email was seldom used though communication

Tab. 4: Communication and information sharing

\begin{tabular}{lcccc}
\hline & N & Mean & $\begin{array}{c}\text { Standard } \\
\text { deviation }\end{array}$ & $\begin{array}{c}\text { Standard } \\
\text { error mean }\end{array}$ \\
\hline Consultants & 57 & 4.68 & 0.478 & 0.110 \\
Subcontractors & 60 & 4.30 & 0.571 & 0.128 \\
Major suppliers & 60 & 4.25 & 0.550 & 0.123 \\
Clients & 63 & 4.43 & 0.746 & 0.163 \\
\hline
\end{tabular}


between subcontractors and main contractors occasionally employed this mode.

It came to light from the interview that these meetings are held on monthly basis and may be reduced to biweekly when a particular project is nearing completion. It was also found out that aside monthly site meetings, technical meetings are scheduled to iron out critical and pressing issues that may arise in between monthly site meetings. Interviewees generally believed that the regular nature of the meetings help to clearly define roles, address issues, set targets and source for ways of achieving them.

Site meetings and technical meetings provided an effective avenue for all parties to deliberate on issues bothering on the smooth execution of projects. It is at these meetings the wide range of issues that will promote the efficient site management and material deliveries were discussed. Other issues include the clarification of discrepancies in working drawings, waste generating activities; any other issues that militate against the smooth execution of projects are looked into and solutions are found. Meetings also served as conflict resolution platform. Since meetings bring together all these players under one umbrella at a time, coordination and collaboration are greatly enhanced.

\subsection{Coordination in planning}

The results prove that generally the various players took into account the concerns of others when planning their activities. This is because there exist healthy relationship among players. Respondents ranked the relationship that exists among them as very healthy. It was found out from the interview with subcontractors that they also see the relationship between themselves, main contractors, consultants and clients as very healthy. Consultants held the same view. The planning of activities by main contractors was influenced to a greater extent by consultants, subcontractors and major suppliers and the reverse also holds true. This explains the higher level of coordination among all parties. It was therefore not surprising to find activities such as defects, unnecessary work, poor storage of materials and poor quality of work not being usual occurrences on-site and hence not sources of waste for the purpose of this study. Coordination in planning of activities by all parties ensures that work is done according to specification, doing the right thing at the right time and allocation of the right type and quantity of materials to the right type of activity. Table 5 summarizes the level of agreement to coordination in planning of activities.
Strong coordination among parties on a project will be stepped in the right direction towards the successful completion of a project. This is because individual companies with separate corporate interests have come together to execute a particular project. One subcontractor who installs lift stated that he can only move to site after the main contractor has finished with all concrete works related to the lift well. He elaborated further that this explains how reliant he is on the main contractor. He however agreed that the main contractor would also have to wait for him to finish with his works before making good any works disturbed. All interviewees agreed that they could hardly achieve the level of success required if they do not take into account the concerns and influences of other players. Team work, to them, is the watch word.

\subsection{Wastes in construction}

For the purpose of this study, waste is understood to be any losses produced by activities that generate direct or indirect costs but do not add any value to the product from the point of view of the client. Respondents understood waste to mean one of the following: leftovers of materials on-site, unwanted material, excess material not used after a construction activity, materials that are supposed to go into the works but do not find their way into the works, percentage of material which was not used as intended as a result of improper usage and/or supervision and any unwanted materials. In line with the set criteria, items $\mathrm{O}-\mathrm{X}$, with mean scores of less than 3 , were considered insignificant.

Another observation was that respondents understood waste from the point of view of one or more of the categories of waste but not certainly all. Subcontractors generally preferred to consider excess materials in inventory as locking up their capital rather than waste. They also understood waste in relation to rework. Different from the above explanations, one respondent understood waste as activities carried out which do not add value and lead to loss of time, quality and cost.

Tab. 5: Coordination in planning of activities

\begin{tabular}{lcccc}
\hline & $\boldsymbol{N}$ & Mean & $\begin{array}{c}\text { Standard } \\
\text { deviation }\end{array}$ & $\begin{array}{c}\text { Standard } \\
\text { error mean }\end{array}$ \\
\hline Consultants & 63 & 4.57 & 0.746 & 0.163 \\
Subcontractors & 60 & 3.65 & 1.137 & 0.254 \\
Major suppliers & 60 & 3.30 & 1.380 & 0.309 \\
Clients & 60 & 4.20 & 1.005 & 0.225 \\
\hline
\end{tabular}


Respondents mostly did not define waste with respect to value adding as $57 \%$ said that it was difficult for them to identify value-adding activities. It gives rise to situations where contractors are not able to identify all wastes and make them targets for reduction or elimination. Site observation confirmed this position because most site supervisors' efforts at waste reduction were geared towards the efficient use of materials to prevent them from being wasted. Very little consideration was given to time-related waste. From the findings, most activities that are timerelated such as delays in arrivals, slow decision-making by consultants and inefficient movement of workers were usual occurrences on-site. On the other hand, activities such as defects, over allocation of materials and work not done, which the respondents considered to generate waste, were not significant to this study, thus giving a clearer picture of the angle from which waste in construction is tackled.

The above can be explained by the fact that $61.9 \%$ of respondents said that they had no tools and techniques that helped them identify waste. In the absence of such tools, it only follows naturally that not all activities that generate waste would be captured. Overwhelming majority of $90.5 \%$ of respondents said that they would like to introduce the concept of lean in their organization to help them identify and eliminate waste. Although most respondents were not familiar with lean concept, after a little explanation, they expressed willingness to adopt such a concept. One respondent, who has some knowledge in lean concept, though accepting to adopt this concept, particularly concerned about the capital intensive nature of its implementation in the initial stages but agreed that it paid off in the long run. This study, however, did not go into the monetary requirements and implications of implementing lean concept in construction.

Identifying value-adding and non-value-adding activities on-site will greatly help in detecting activities that generate waste and subsequently target them for reduction and/or elimination.

\section{Conclusion}

Clients have become increasingly demanding and require products and services at lower cost, higher quality, shorter execution duration and more reliable schedule. In response to this, industries are reviewing their operations to meet the demands of the end user. In the light of the above, the author sorted to study into how SCM can benefit

Tab. 6: Sources of waste

\begin{tabular}{|c|c|c|c|c|c|}
\hline Item & & $N$ & Mean & Standard deviation & Standard error mean \\
\hline A & Delays in arrival of workers, plant and materials & 63 & 3.7619 & 0.70034 & 0.15283 \\
\hline $\mathrm{B}$ & Slow decision-making and instructions by consultants & 63 & 3.6190 & 0.74001 & 0.16148 \\
\hline $\mathrm{C}$ & Waste of materials & 63 & 3.5238 & 0.74960 & 0.16358 \\
\hline $\mathrm{D}$ & Shortage of materials & 63 & 3.5238 & 0.87287 & 0.19048 \\
\hline $\mathrm{E}$ & Inefficient movement of workers & 63 & 3.3810 & 0.80475 & 0.17561 \\
\hline $\mathrm{F}$ & Poorly scheduled delivery of materials to site & 63 & 3.2857 & 0.84515 & 0.18443 \\
\hline G & Accidents & 63 & 3.2381 & 0.62488 & 0.13636 \\
\hline $\mathrm{H}$ & Excess materials in store & 63 & 3.1905 & 0.92839 & 0.20259 \\
\hline 1 & Waiting and idling & 63 & 3.1905 & 0.92839 & 0.20259 \\
\hline$J$ & Double handling of materials & 63 & 3.1429 & 0.91026 & 0.19863 \\
\hline $\mathrm{K}$ & Use of materials over and above specifications & 63 & 3.1429 & 0.96362 & 0.21028 \\
\hline $\mathrm{L}$ & Deterioration of materials & 63 & 3.0952 & 0.76842 & 0.16768 \\
\hline M & Rework & 63 & 3.0476 & 0.80475 & 0.17561 \\
\hline $\mathrm{N}$ & Unnecessary or not enough information flow & 63 & 3.000 & 0.89443 & 0.19518 \\
\hline 0 & Waste of space on-site & 63 & 2.9524 & 0.74001 & 0.16148 \\
\hline $\mathrm{P}$ & Defects & 63 & 2.9524 & 0.74001 & 0.16148 \\
\hline Q & Work not done & 63 & 2.9524 & 0.86465 & 0.18868 \\
\hline $\mathrm{R}$ & Over allocation of materials to an activity & 63 & 2.9524 & 0.97346 & 0.21243 \\
\hline $\mathrm{S}$ & Unnecessary work & 63 & 2.9048 & 0.88909 & 0.19401 \\
\hline $\mathrm{T}$ & Poor quality of materials & 63 & 2.8571 & 0.79282 & 0.17301 \\
\hline $\mathrm{U}$ & Poor storage of materials & 63 & 2.8095 & 0.74960 & 0.16358 \\
\hline V & Workers performing activities well below their capabilities & 63 & 2.8095 & 0.87287 & 0.19048 \\
\hline W & Abnormal use of equipment and tools & 63 & 2.7143 & 0.84515 & 0.18443 \\
\hline$X$ & Inadequate storage spaces & 63 & 2.7143 & 0.84515 & 0.18443 \\
\hline
\end{tabular}


the Ghanaian building construction industry through the application of lean concept. Specific areas that were target for study were to assess the level of collaboration and coordination in planning of activities among construction players and the sources of waste in construction.

Waste reduction is the best and usually the most economical of the different management alternatives. This is achieved by avoiding activities that do not add value to the customer, while keeping quality requirements intact. To implement an efficient waste reduction programme in the Ghanaian building construction industry, it is necessary to identify what is generating waste and its causes.

Results showed that there exist commendable level of collaboration and cooperation among industry players. This position is further reinforced by the study pointing out that stakeholders share information freely among themselves while taking into account the interest of others when planning activities.

Additionally, the study indicated that concepts such as waste and value are not well understood by construction personnel. The personnel often do not realize that many activities they carry out do not add value to the work. These issues contribute to a reduction in the value of construction productivity and could reduce a company's performance and profitability. By identifying the incidence of waste during a project, construction personnel are able to easily identify the best solutions and ways to apply new technique for reducing the amount of waste, leading to increase project productivity.

\section{Research limitation and future direction}

The study was situated geographically within the confines of KNUST, covering contractors in the financial classification of D1K1. To better understand the entirety of the construction industry in Ghana with regard to lean construction, further studies are recommended incorporating contractors in the other three financial classifications. Furthermore, broadening the scope to include other government agencies and sectors, as well as the private sector, will paint a much holistic picture.

\section{References}

Aamer, A. M. (2018). Outsourcing in non-developed supplier markets: A lean thinking approach. International Journal of Production Research, 56(18), pp. 6048-6065.
Ahmad, M. O., Kuvaja, P., Oivo, M., \& Markkula, J. (2016). Transition of software maintenance teams from scrum to Kanban. In: Proceedings of $49^{\text {th }}$ Hawaii International Conference on System Sciences (HICSS), Koloa, HI, USA, 5-8 January 2016.

Ayarkwah, J., Agyekum, K., \& Adinyira, E. (2011). Barriers to sustainable implementation of lean construction in the Ghanaian building industry. In: Proceedings of 6 th Built Environment Conference, JHB, South Africa, July 31-Aug. 2.

Ayarkwah, J., Agyekum, K., Adinyira, E., \& Osei-Asibey, D. (2012a). Perspectives for the implementation of lean construction in the Ghanaian construction industry. Journal of Construction Project Management, 2(2), pp. 345-359.

Ayarkwah, J., Agyekum, K., Adinyira, E., \& Osei-Asibey, D. (2012b). Barriers to successful implementation of lean construction in the Ghanaian building industry. Journal of Construction, 5(21), pp. 3-11.

Aziz, R. M., \& Hafez, S. M. (2013). Applying lean thinking in construction and performance improvement. Alexandria Engineering Journal, 52(4), pp. 679-695. doi: 10.1016/j. aej.2013.04.008.

Badri, H., Bashiri, M., \& Hejazi, T. H. (2013). Integrated strategic and tactical planning in a supply chain network design with a heuristic solution method. Computers \& Operations Research, 40(4), pp. 1143-1154.

Christopher, M. (2016). Logistics and Supply Chain Management, 5 th edn. Pearson Education Limited, Harlow.

Creswell, J. W. (2013). Research Design Qualitative, Quantitative and Mixed Methods Approaches, 4th edn. Sage Publications, London.

Dave, B., Kubler, S., Framling, K., \& Koskela, L. (2016). Opportunity for enhanced lean construction management using internet of things standards. Automation in construction, 61, pp. 89-97. doi: 10.1016/j.autcon.2015.10.009.

Fitzsimmons, J. A., \& Fitzsimmons, M. J. (2011). Service Management: Operations, Strategy, Information Technology, 7th edn. McGraw-Hill, London.

Gustafsson, J. (2017). Single case studies vs multiple case studies: A comparative study. Halmstad University. School of Business, Engineering and Science. Available at http://urn.kb.se/ resolve?urn=urn:nbn:se:hh:diva-33017.

Ho, C. H., \& Kuo, J. D. (2015). Making formwork construction lean. Journal of Civil Engineering and Management, 21(4), pp. 444-458.

Holmemo, M. D. Q., Rolfsen, M., \& Ingoaldsen, J. A. (2018). Lean thinking: Outside-in, bottom-up? The paradox of contemporary soft lean and consultant-driven lean implementation. Total Quality Management and Business Excellence, 29(2), pp. 148-160.

Holweg, M. (2007). The genealogy of lean production. Journal of Operations Management, 25(2), pp. 420-437.

Koskela, L. (2004). Moving on - beyond lean thinking. Lean Construction Journal, 1(1), pp. 24-37.

Liker, J. K. (2004). The Toyota Way: 14 Management Principles from the World's Greatest Manufacturer. McGraw-Hill, New York, London.

Liu, R., \& Chua, V. C. (2016). Theoretical digitization of information flow in the construction supply chain. International Journal of Management Research and Business Strategy, 5(1), pp. 10-27. 
Ma, J., Lin, Z., \& Lau, C. (2017). Prioritizing the enablers for the successful implementation of kaizen in China. International Journal of Quality and Reliability Management, 34(4), pp. 549-568.

Moaveni, S., Banihashem, S. Y., \& Mojtahedi, M. (2019). A conceptual model for a safety-based theory of lean construction. Buildings, 9(23), doi: 10.3390/ buildings 9010023.

Nikakhtar, A., Hosseini, A. A., Wong, K. Y., \& Zavichi, A. (2015). Application of lean construction principles to reduce construction process waste using computer simulation: A case study. International Journal of Services and Operations Management, 20(4), pp. 461-480.

O’Brien, W. J., Formoso, C. T., Vrijhoef, R., \& London, K. A. (2008). Construction Supply Chain Management Handbook. CRC Press, New York.

Ofori, G. (2012). Developing the Construction Industry in Ghana: The Case of a Central Agency. National University of Singapore, Singapore. Available at www.ghanatrade.com.gh/file/ Developing the Construction Industry in Ghana BUILDING.pdf.

Ofori, G., Gang, G., \& Briffet, C. (2012). Implementing environmental management systems in construction: Lessons from quality systems. Building and Environment, 37(12), pp. 397-407.
Randhawa, J. S., \& Ahuja, I. S. (2017). 5s - A quality improvement tool for sustainable performance: Literature review and directions. International Journal of Quality and Reliability Management, 34(3), pp. 334-361.

Robson, C. (2002). Real World Research, 2nd edn. Blackwell, Oxford.

Stock, J. R., \& Boyers, S. L. (2009). Developing a consensus definition of supply chain management: A qualitative study. International Journal of Physical Distribution \& Logistics Management, 39(8), pp. 690-711.

Sutrisno, A., Vanany, I., Gunawau, I., \& Asjad, M. (2018). Lean waste classification model to support the sustainable operational practice. IOP Conference Series: Materials Sciences and Engineering, 337, p. 012067. doi: 10.1008/1757899×1337/1/012067.

Tezel, A., Koskela, L., \& Aziz, Z. (2013). Lean thinking in the highways construction sector: Motivation, implementation and barriers. Production Planning and Control. The Management of Operations, 29(3), pp. 247-269.

Vidhate, T., \& Salunkhe, A. A. (2018). General overview of lean management in construction industry. International Journal of Engineering and Technology (IRJET), 5(7), pp. 1999-2004.

Yin, R. K. (2017). Case Study Research: Design and Methods, 6th edn. Sage Publications, Thousand Oaks, CA. 